http://dx.doi.org/10.18778/1644-857X.16.02.19

\title{
Sprawozdanie z Jubileuszu 60-lecia urodzin profesora Zbigniewa Anusika, Łódź, 8 grudnia 2017 r.
}

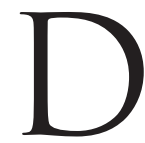
nia 8 grudnia 2017 r. w Sali Rady Wydziału Filozoficzno-Historycznego Uniwersytetu Łódzkiego (UŁ) odbył się Jubileusz 60-lecia urodzin prof. zw. dra hab. Zbigniewa Anusika, połączony $z$ wręczeniem dedykowanej Jubilatowi książki pt. Sic erat in votis. Studia i szkice ofiarowane Profesorowi Zbigniewowi Anusikowi w sześćdziesiąta rocznice urodzin, która ukazała się pod redakcja dr Małgorzaty Karkochy i dra Piotra Robaka, nakładem wydawnictwa Uniwersytetu Łódzkiego ${ }^{1}$. Uroczystość została przygotowana przez Katedrę Historii Nowożytnej UŁ, której Pan Profesor jest kierownikiem. W spotkaniu uczestniczyli Jego Magnificencja Rektor UŁ, prof. dr hab. Antoni Różalski, Kolegium Dziekańskie Wydziału Filozoficzno-Historycznego UŁ, dyrekcja Instytutu Historii, przedstawiciele Zarządu Głównego Polskiego Towarzystwa Historycznego (PTH) z prof. drem hab. Krzysztofem Mikulskim na czele, władze Oddziału PTH w Łodzi, w Zarządzie którego zasiada prof. Z. Anusik, licznie reprezentowani pracownicy Wydziału Filozoficzno-Historycznego naszej Almae Matris, autorzy tekstów do księgi jubileuszowej, wreszcie studenci, uczniowie, przyjaciele i rodzina Pana Profesora.

Uroczystość otworzył Komitet Organizacyjny w osobie dr Małgorzaty Karkochy i dra Piotra Robaka. Przywitali oni serdecznie dostojnego Jubilata, zaproszonych gości oraz wszystkich zgromadzonych na sali. Doktor M. Karkocha przybliżyła pokrótce cel

1 Sic erat in votis. Studia i szkice ofiarowane Profesorowi Zbigniewowi Anusikowi $w$ sześćdziesiata rocznice urodzin. Rzeczpospolita $w$ czasach nowożytnych, red. M. Karkocha, P. Robak, Łódź 2017, ss. 504; Sic erat in votis. Studia i szkice ofiarowane Profesorowi Zbigniewowi Anusikowi w sześćdziesiata rocznice urodzin. Europa $i$ świat w czasach nowożytnych, red. eorundem, Łódź 2017, ss. 400. 
uroczystości i zaprezentowała dwutomową księge jubileuszową. Poinformowała, że o napisanie tekstów poproszono zaprzyjaźnionych $z$ Panem Profesorem badaczy $z$ różnych ośrodków naukowych w kraju i zagranicy. Artykuły nadesłało ostatecznie 40 uczonych - historyków, historyków sztuki i archeologów. W tomie I znalazły się teksty dotyczące dziejów Polski, w tomie II - dziejów powszechnych lub z pogranicza historii Polski i powszechnych. Dotycza one różnorakiej problematyki. Omawiają zagadnienia polityczne, militarne, ustrojowe, społeczne, obyczajowe, a także poruszają tematy z zakresu historiografii, antropologii historycznej, historii podróży, miast, sądownictwa, skarbowości, wreszcie historii sztuki i myśli politycznej. Taka różnorodność tematyki zamieszczonych $\mathrm{w}$ księdze studiów odzwierciedla niezwykle szerokie zainteresowania badawcze $Z$. Anusika. Na zakończenie dr M. Karkocha wyraziła wdzięczność autorom za trud i czas, jaki włożyli w przygotowanie nadesłanych do druku tekstów. Podziękowała również obecnym na sali recenzentom: prof. prof. Marianowi Drozdowskiemu z Akademii Pomorskiej w Słupsku i Stanisławowi Roszakowi z Uniwersytetu Mikołaja Kopernika w Toruniu.

Następnie dr P. Robak przybliżył sylwetkę naukową prof. Z. Anusika i przedstawił znane i mniej znane fakty $z$ życia Jubilata. W czasie jego wystapienia wyświetlana była prezentacja multimedialna ukazująca Pana Profesora w różnych odsłonach - jako poważnego naukowca, ale też w sytuacjach mniej oficjalnych, w otoczeniu przyjaciół i rodziny. Wzbudziła ona zaciekawienie zebranych i wywołała na ich twarzach uśmiech.

Przypomnijmy zatem, że prof. Zbigniew Włodzimierz Anusik urodził się w 1957 r. w Łodzi. Tu też w roku 1976 ukończył II Liceum im. Gabriela Narutowicza i został przyjęty w poczet studentów historii UŁ. Cztery lata później złożył egzamin magisterski na podstawie pracy pt. Życie polityczne $w$ Piotrkowie $w$ XVI-XVIII wieku, napisanej pod kierunkiem prof. dra hab. Bohdana Baranowskiego, i jeszcze $\mathrm{w}$ tym samym roku został zatrudniony na stanowisku asystenta w Zakładzie Historii Powszechnej Nowożytnej i Najnowszej w Instytucie Historii UŁ. W grudniu 1990 r. obronił rozprawe doktorska pt. Misja polska $w$ Sztokholmie w latach 1789-1795, przygotowana pod kierunkiem prof. dr Zofii Libiszowskiej, miesiąc później zaś Rada Wydziału Filozoficzno-Historycznego UŁ nadała mu stopień doktora nauk humanistycznych. W roku 2001 r. odbyło się jego kolokwium habilitacyjne na podstawie pracy Dyplomacja 
szwedzka wobec kryzysu monarchii we Francji w latach 1787-1792 i moca uchwały wspomnianej Rady uzyskał stopień naukowy doktora habilitowanego nauk humanistycznych w zakresie historii. W 2003 r. został powołany na stanowisko profesora nadzwyczajnego UŁ, jednak już w 2007 r. prezydent Rzeczpospolitej Polskiej Lech Kaczyński nadał mu tytuł naukowy profesora nauk humanistycznych. W roku $2005 \mathrm{Z}$. Anusik obją kierownictwo samodzielnego Zakładu Historii Nowożytnej Krajów Nadbałtyckich, od 2006 r. kierował Katedrą Historii Nowożytnej Polski i Krajów Nadbałtyckich, a od 2011 r. jest kierownikiem Katedry Historii Nowożytnej. Zainteresowania naukowe Jubilata koncentrują się wokół szeroko pojętej historii Polski i powszechnej XVII-XVIII stulecia. Od przeszło 30 lat zajmuje się także badaniami związanymi $z$ nowożytną historią Szwecji, dziejami ówczesnych stosunków polsko-szwedzkich oraz historia dyplomacji polskiej i powszechnej XVIII w. W ostatnich dwóch dekadach coraz więcej miejsca w swoich badaniach poświęcił wydarzeniom Wielkiej Rewolucji Francuskiej i międzynarodowym oddziaływaniom wypadków zachodzących we Francji w latach 1787-1799. Pan Profesor był dwukrotnym stypendysta Instytutu Szwedzkiego (Sveriges Institutet) (w latach 1987-1988 i 1992-1993), Fundacji im. Stefana Batorego (1996) oraz Fundacji z Brzezia Lanckorońskich (1997). Umożliwiło mu to prowadzenie kwerendy źródłowej w Archiwum Narodowym Szwecji (Riksarkivet) i podjęcie badań naukowych na Uniwersytecie w Oksfordzie (Wolfson College). Jubilat może poszczycić się imponującym wręcz dorobkiem naukowym. Opublikował ponad 200 publikacji o charakterze naukowym, w tym siedem książek. Jego rozprawa habilitacyjna oraz biografie władców Szwecji: Gustawa II Adolfa i Karola XII zyskały uznanie w środowisku historyków. Zostały też wyróżnione nagrodą indywidualną Rektora UŁ. Dodać należy, że $Z$. Anusik był pomysłodawca i współtwórca (wraz z prof. Albinem Głowackim) wydawanego od 2002 r. przez Instytut Historii UŁ półrocznika „Przegląd Nauk Historycznych”. Jest również redaktorem czasopisma „Acta Universitatis Lodziensis”, Folia Historica. Poza tym Pan Profesor pełnił szereg ważnych funkcji administracyjnych, dydaktycznych i organizacyjnych w macierzystej uczelni. W latach 1999-2002 był pełnomocnikiem dyrektora Instytutu Historii ds. dydaktycznych, a w latach 2000-2008 kierownikiem Podyplomowego Studium Historii oraz Historii i Wiedzy o Społeczeństwie. Ostatnie stanowisko łączył z obowiązkami prodziekana Wydziału 


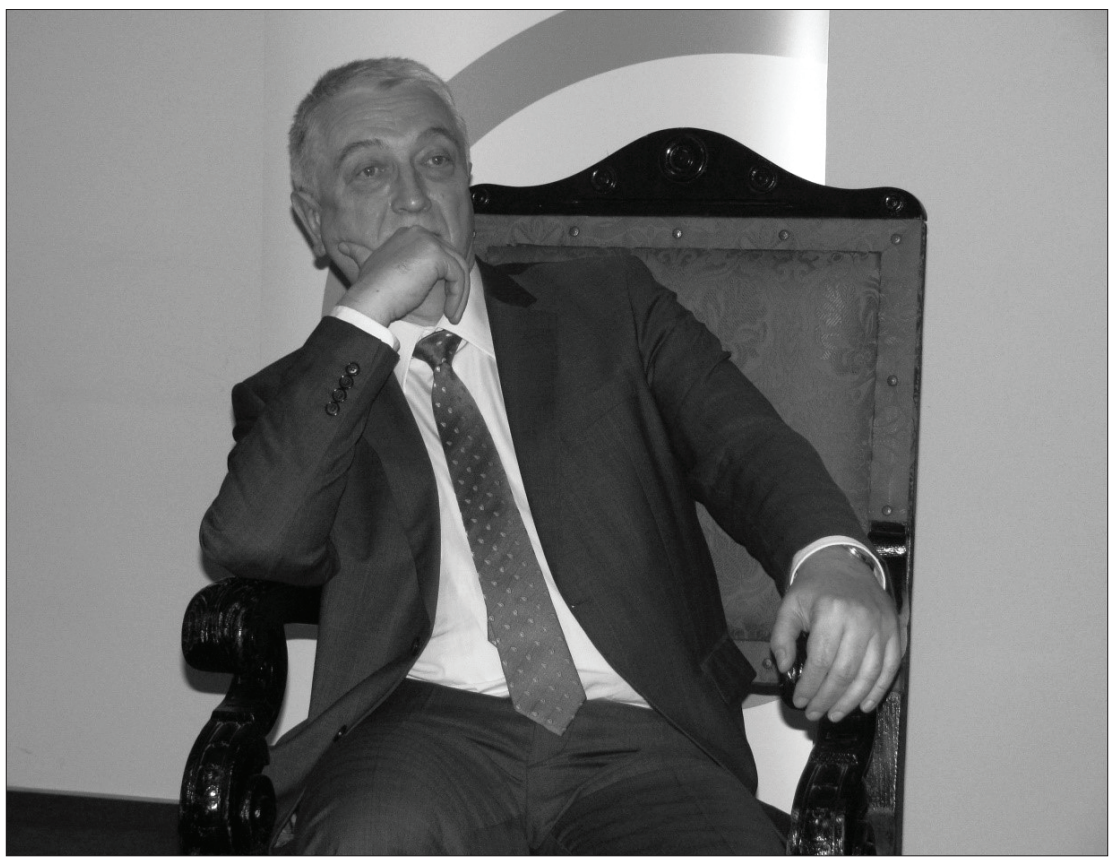

1. Bohater uroczystości - prof. Z. Anusik. Fot. J. Frenkel

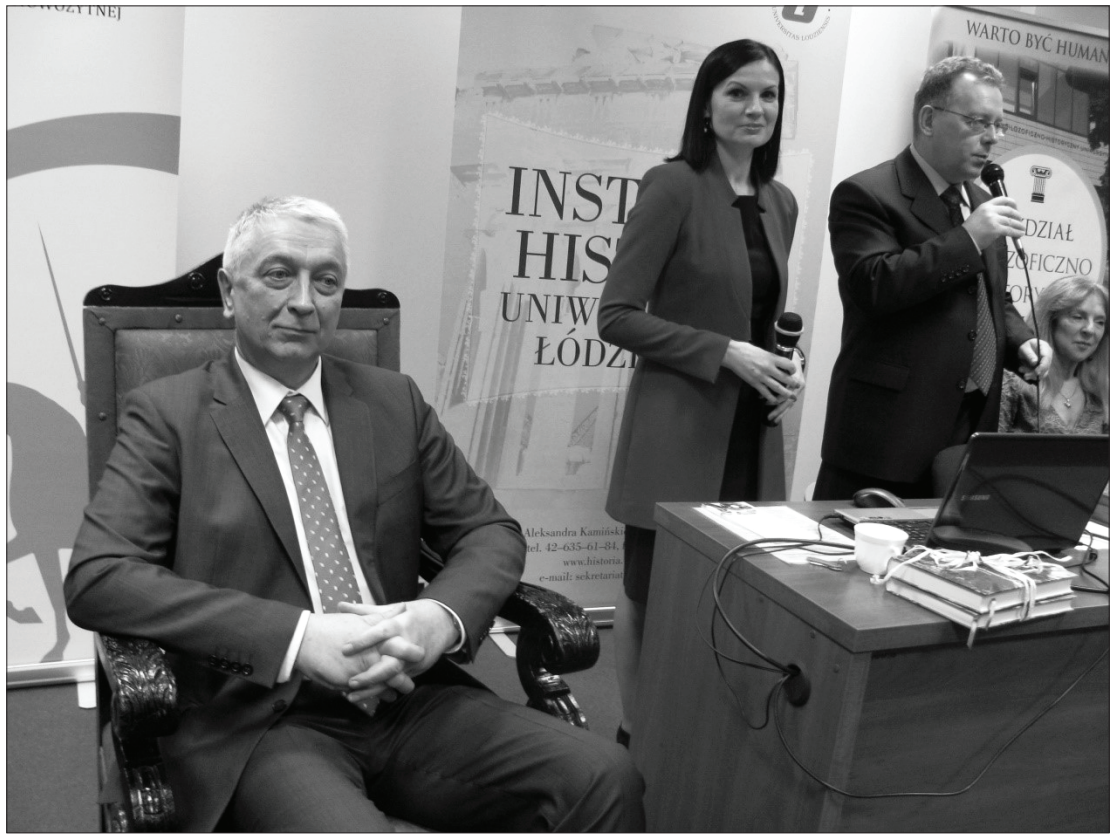

2. Jubileusz 60-lecia urodzin prof. Z. Anusika (od lewej: Jubilat, prowadzacy spotkanie dr M. Karkocha i dr P. Robak, prof. J. Daszyńska). Fot. J. Frenkel 


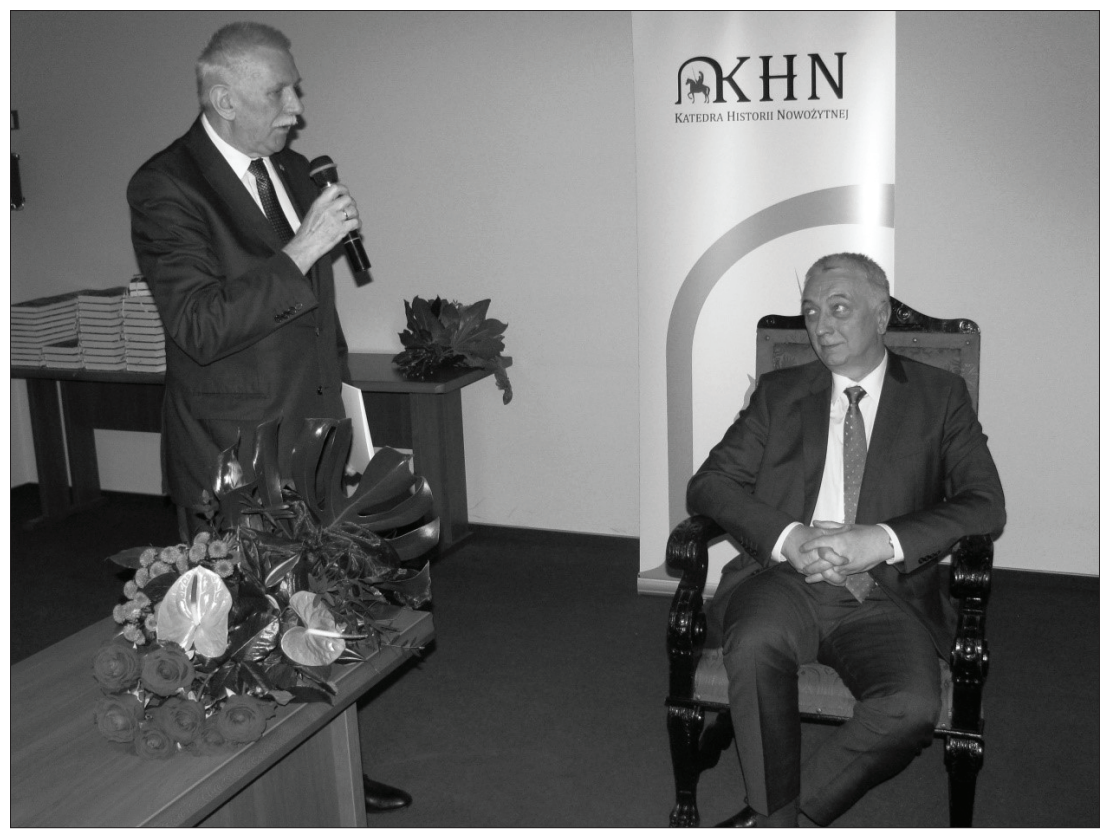

3. Przemówienie Jego Magnificencji Rektora UŁ, prof. dra hab. Antoniego Różalskiego. Fot. J. Frenkel

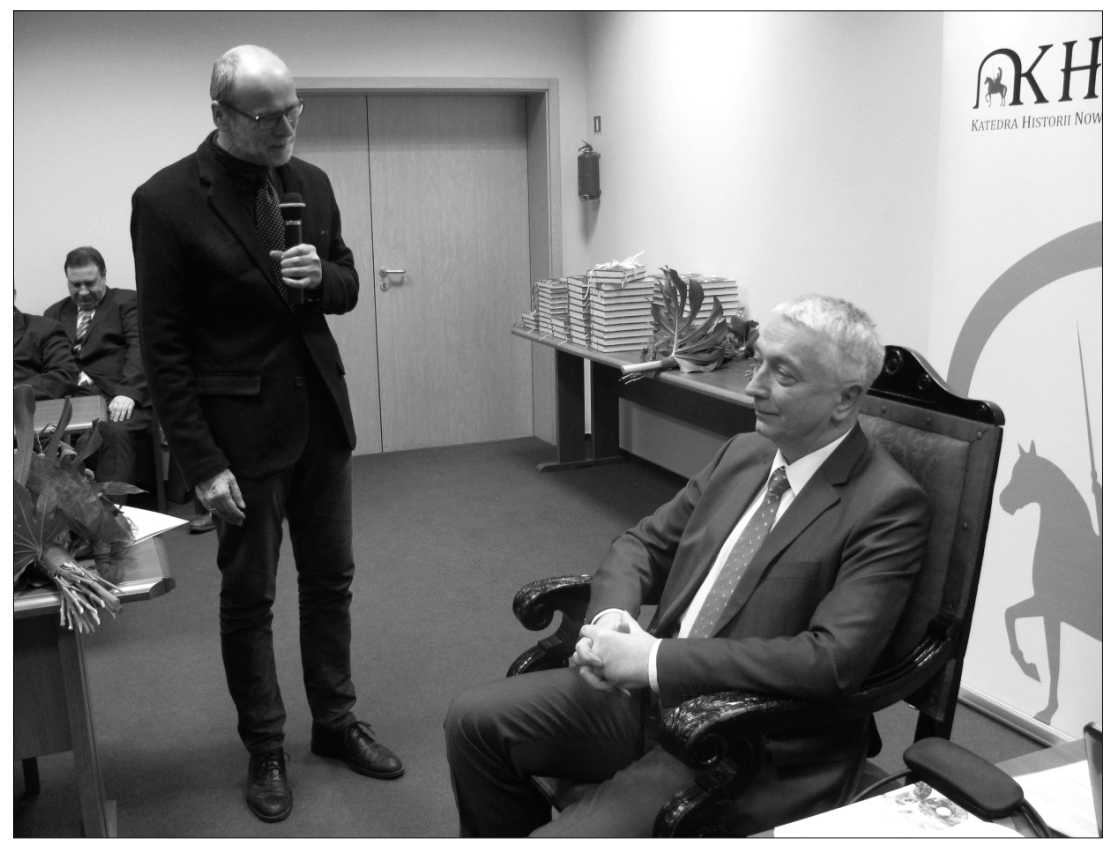

4. Dziekan Wydziału Filozoficzno-Historycznego UŁ prof. dr hab. Maciej Kokoszko składajacy gratulacje i życzenia Z. Anusikowi. Fot. J. Frenkel 
Filozoficzno-Historycznego UŁ (od 2002) oraz dyrektora Instytutu Historii (od 2005). W latach 2008-2016 był dziekanem wspomnianego wydziału. Nie przeszkodziło mu to jednak wypromować 11 doktorów i blisko 100 magistrów. W uznaniu zasług dla UŁ Jubilat został uhonorowany licznymi odznaczeniami, m.in. Złota Odznaką UŁ (2001), Medalem UŁ w służbie społeczeństwu i nauce (2010), Medalem Srebrnym za długoletnią służbę (2008), Medalem Złotym za długoletnią służbę (2013) oraz szczególnie cenionym przez nauczycieli akademickich Medalem Komisji Edukacji Narodowej (2012). Przyznano mu nadto szereg nagród indywidualnych i zespołowych Rektora UŁ (I i II stopnia). Profesor Z. Anusik uwielbia podróże i sport. W młodości grywał w koszykówkę, do czego predysponowały go warunki fizyczne, a obecnie jest zapalonym kibicem klubu piłkarskiego Widzew Łódź. Jest też nieocenionym uczestnikiem spotkań towarzyskich, albowiem lubi śpiewać i tańczyć - w obu tych dziedzinach wykazuje zreszta prawdziwy talent.

W dalszej części spotkania prowadzący poprosili o zabranie głosu Jego Magnificencję Rektora UŁ, prof. dra hab. Antoniego Różalskiego, Dziekana Wydziału Filozoficzno-Historycznego UŁ, prof. dra hab. Macieja Kokoszkę, dyrektora Instytutu Historii, prof. dra hab. Dariusza Jeziornego, prezesa PTH, prof. dra hab. Krzysztofa Mikulskiego oraz prezes Oddziału Łódzkiego tego Towarzystwa, prof. dr hab. Jolantę Daszyńską. Wszyscy oni podkreślali niewątpliwe zasługi Jubilata dla Instytutu Historii, Wydziału Filozoficzno-Historycznego i samej uczelni. Gratulowali mu dotychczasowych sukcesów i życzyli dalszych osiagnięć na niwie zawodowej oraz w życiu prywatnym. Szczególnie ciepłe i osobiste było wystapienie prof. J. Daszyńskiej. Mówiła ona o początkach znajomości z Panem Profesorem i o łączącej ich wieloletniej przyjaźni. Przedstawiła Jubilata jako osobę serdeczna, życzliwa, oddaną nauce i rodzinie, a do tego skromną i niezwykle pracowita.

Następnie odczytano listy gratulacyjne nadesłane przez prof. prof. Mirosława Nagielskiego (Uniwersytet Warszawski, dalej: UW), Richarda Butterwicka-Pawlikowskiego (Instytut Historii im. Tadeusza Manteuffla Polskiej Akademii Nauk, University College London) oraz Waldemara Kowalskiego (Uniwersytet Jana Kochanowskiego w Kielcach), po czym głos zabrały osoby $z$ sali. Były Rektor UŁ prof. dr hab. Wiesław Puś mówił o tym, że Z. Anusik jako dziekan Wydziału Filozoficzno-Historycznego UŁ przykładał olbrzymia wage do sprawy parametryzacji. Przyznał, że podczas 
jego kadencji zdarzało mu się nierzadko wchodzić $z$ nim w polemikę, teraz jednak nie pozostaje mu nic innego, jak złożyć Jubilatowi gratulacje i podziękować za sukces osiaggnięty przez Wydział Filozoficzno-Historyczny dzięki konsekwencji i wymaganiom stawianym przez Pana Profesora. Profesor Stanisław Roszak w anegdotyczny sposób wspomniał trzy sprawy, które od dawna wiązały $Z$. Anusika $z$ Toruniem. Pierwsza $z$ nich było pokonanie przez Jubilata podczas II edycji Olimpiady Historycznej w 1975 r. Bogusława Dybasia, profesora reprezentowanej przez siebie uczelni. Cofnał się również pamięcią do czasów, kiedy uczęszczał na seminarium magisterskie. Podkreślił, że jego mentor - prof. Jacek Staszewski zwykł kłaść blisko biurka książki uważane przez siebie za cenne pod względem merytorycznym i właśnie to miejsce zajmowały publikacje Pana Profesora. Na zakończenie nadmienił o swojej uczennicy, dr Joannie Orzeł, od niedawna zatrudnionej na stanowisku adiunkta w Katedrze Historii Nowożytnej UŁ. Składając najlepsze życzenia, wręczył Jubilatowi prezent w postaci pierników oraz „eliksiru szczęścia i długowieczności” własnego wyrobu. Profesor Dariusz Rolnik powinszował Z. Anusikowi dotychczasowych osiagnięć naukowych i odczytał List Gratulacyjny dyrektora Instytutu Historii Uniwersytetu Ślaskiego, prof. dra hab. Jerzego Sperki. W imieniu własnym oraz reprezentowanej przez siebie uczelni życzenia i gratulacje złożył Panu Profesorowi także dr hab. Adam Perłakowski (Uniwersytet Jagielloński w Krakowie).

Po kilku ciepłych słowach wypowiedzianych przez magistranta Daniela Kasprowicza, który nadmienił, że nie zdecydowałby się na studia historyczne, gdyby nie lektura Gustawa II Adolfa pióra $Z$. Anusika, nadszedł czas na główny punkt programu - wręczenie Jubilatowi dwutomowej księgi pamiątkowej, nad którą komitet redakcyjny pracował bez mała półtora roku. Następnie prowadzacy oddali głos Bohaterowi spotkania. Ten rozpoczą od serdecznych podziękowań dla Rektora UŁ, władz Wydziału Filozoficzno-Historycznego i PTH, autorów tekstów zamieszczonych w księdze jubileuszowej, rodziny oraz współpracowników. W sposób szczególny podziękował dr M. Karkosze za trud włożony w przygotowanie poświęconej mu publikacji, jak również samej uroczystości. Nadmienił dalej, że jego losy już od momentu narodzin związane były $z$ okolica, w której znajduje się gmach Wydziału Filozoficzno-Historycznego UŁ. Urodził się bowiem w pobliskim szpitalu Ministerstwa Spraw Wewnętrznych i Administracji na ul. Północnej 42, a do szkoły 
średniej uczęszczał na ul. Nową 11/13 (II Liceum Ogólnokształcące im. Gabriela Narutowicza). Decyzja o wyborze studiów nie była jednak tak oczywista. Profesor Z. Anusik przyznał, że dzięki wysokiej nocie uzyskanej w finale II Olimpiady Historycznej właściwie każda uczelnia w kraju stała dla niego otworem. Zastanawiał się więc nad dziennikarstwem i historia na UW i historią na UŁ. Na szczęście dla łódzkiego środowiska historycznego Z. Anusik podjął studia na ostatniej $z$ tych uczelni. Jubilat zweryfikował też informację na temat otrzymanej księgi, stwierdzając, że tak naprawdę są to dwie odrębne publikacje.

Ostatnim punktem spotkania było wręczenie księgi jubileuszowej autorom tekstów oraz gościom honorowym. Po uroczystości nastapiły życzenia i gratulacje składane na ręce Pana Profesora. Była także okazja do zrobienia sobie $z$ nim wspólnej, pamiątkowej fotografii. Profesorowi $Z$. Anusikowi gratulujemy tego pięknego jubileuszu i życzymy mu zdrowia, dalszych sukcesów naukowych oraz wielu jeszcze ciekawych książek i artykułów.

Matgorzata KarKocha

UNIWERSYTET ŁÓDZKI

*Wydział Filozoficzno-Historyczny, Instytut Historii, Katedra Historii Nowożytnej, e-mail: malkarkocha@o2.pl. 